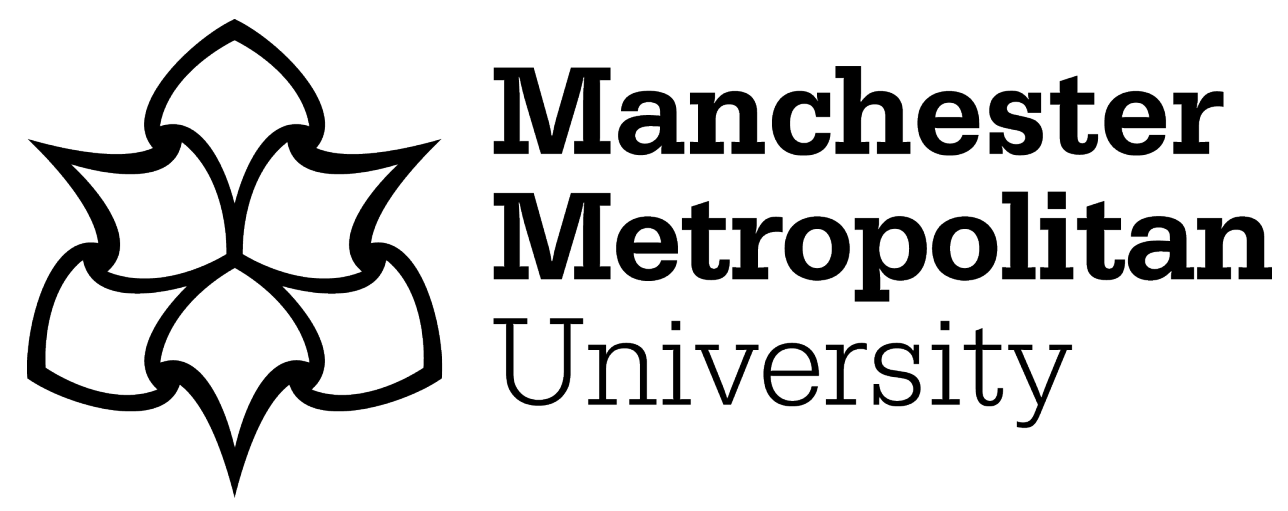

Slate, AJ, Karaky, N and Whitehead, KA (2018) Antimicrobial properties of modified graphene and other advanced 2D material coated surfaces. In: 2D materials: Characterization, production and applications. CRC Press. ISBN 9781498747394

Downloaded from: https://e-space.mmu.ac.uk/617974/

Version: Accepted Version

Publisher: CRC Press

Please cite the published version 


\section{Antimicrobial Properties of Modified Graphene and other Advanced 2D Material Coated}

\section{Surfaces}

Anthony J. Slate ${ }^{1,2}$, Nathalie Karaky ${ }^{1}$, Kathryn A. Whitehead ${ }^{1 *}$

${ }^{1}$ Centre for Biomedicine, Manchester Metropolitan University, Manchester M1 5GD, UK.

${ }^{2}$ Division of Chemistry and Environmental Science, Manchester Metropolitan University, Manchester M1 5GD, UK.

Corresponding Author: K. A. Whitehead, School Healthcare Science, Manchester Metropolitan University, UK. Tel: +441612471157 E-mail: ‥A.Whitehead@mmu.ac.uk

Keywords: Graphite, graphite oxide, reduced graphite, graphene, graphene oxide, reduced graphene oxide, bacteria, antimicrobial resistance, advanced 2D materials, surfaces.

\section{Introduction}

Over recent decades, antimicrobial resistance (AMR) has emerged as an enormous global issue. The rise in observed AMR bacteria can be attributed to the continuous overuse of antimicrobial therapies, not limited to healthcare but within a wide range of areas including in the veterinary services and agriculture. ${ }^{1}$ The problems with the overuse of antibiotics has been coupled with the lack of new antibiotic therapies. A number of pharmaceutical companies have abandoned research in the antibiotic field which has led to a lack of compounds able to effectively treat AMR bacteria. ${ }^{2}$ The continual over reliance placed upon antibiotics, along with a better infrastructure in society has led to geographical barriers no longer being an issue. This has resulted in the unrestricted movement of people, products and their microbial counterparts. Coinciding with this increase in movement has been the evolution of bacteria, which has allowed genes coding for antimicrobial resistance to be developed, shared and expressed by a number of different bacterial species. Once a resistance gene is produced, it is able to be transferred to other bacteria (both of the same and different genus) by horizontal gene transfer, therefore the potential to spread through the bacterial population is high. ${ }^{3}$ The result has been specific antimicrobial agents becoming ineffective and therefore impractical against certain bacterial strains. ${ }^{4}$ In light of this, emphasis must be placed on the development of alternative antimicrobial agents in order 
to reduce the transmission of microbial agents and the burden placed upon conventional (antibiotic) therapies.

Antimicrobial resistance is an issue within a wide range of infectious organisms. The "ESKAPE" pathogens include Enterococcus spp., Staphylococcus aureus, Klebsiella pneumoniae, Acinetobacter baumannii, Pseudomonas aeruginosa and Enterobacter spp. These pathogens demonstrate high levels of multidrug resistance, and are responsible for a substantial percentage of nosocomial infections. ${ }^{5}$ The magnitude of this worldwide problem and the impact of AMR on human health, results in increased costs for the health-care sector. Further, the wider societal impact of such infections are of key concerns for governments. A report by the World Health Organisation (WHO) reported than an average of $8.7 \%$ of hospital patients had nosocomial infections. The costs associated with this include an increased length of stay for infected patients, the increased use of drugs, additional laboratory costs, possibility of the need for isolation and increased morbidity and mortality rates. Since the issues associated with AMR include a number of areas outside the health sector, WHO estimated over 10 years ago that this phenomenon would result in a fall in real gross domestic product (GDP) of $0.4 \%$ to $1.6 \%$ (which is equivalent to several billions of today's dollars) ${ }^{6}$. Being a complex global public health challenge, no single or simple strategy will suffice to fully contain the emergence and spread of nosocomial and community acquired infectious organisms that become resistant to available antimicrobial drugs.

Within nature, cells living freely in bulk solution usually become attached to a surface, and if retained, can then form a biofilm. A biofilm is a matrix-enclosed bacterial populations that are attached to a surface or an interface. Biofilms demonstrate a wide array of resistance mechanisms, including persistent dormant cells, hyper-mutability, quorum sensing and efflux pumps making them extremely tolerant / resistant to antibiotics and antimicrobials and thus greater antimicrobial resistance has been demonstrated in biofilms when compared to planktonic cells. ${ }^{7,8}$ Thus, there is a need for advanced antimicrobial surfaces to be developed. A range of 2D-nanomaterials that may be exploited is antimicrobial surface coatings, which could be used in areas with a population that is of increased risk of potential microbial / bacterial transfer, e.g. nosocomial settings. These include the carbon based materials such as graphite, graphite oxide, reduced graphite oxide, graphene, graphene oxide and 
reduced graphene oxide and non-carbon based materials for example boron nitrite, tungsten diselenide and molybdenum disulphide.

\section{Carbon-Based Nanomaterials}

The graphite and graphene derivatives have specific definitions (Table 1). There are a number of graphite and graphene derivatives (Table 2) that have been used in nanoparticulate and 2D form to determine their antimicrobial activity.

Table 1. Definitions of the graphene / graphite derivatives

\begin{tabular}{|c|c|}
\hline Graphite / Graphene Type & Definition \\
\hline Graphite & $\begin{array}{l}\text { In graphite, adjacent graphene layers overlap due } \\
\text { to } p_{z} \text { orbitals, producing bulk graphite. }{ }^{9}\end{array}$ \\
\hline Graphite oxide & $\begin{array}{l}\text { Graphite oxide refers to graphite with functional } \\
\text { groups containing oxygen attached. It is prepared } \\
\text { by treating graphite with strong aqueous } \\
\text { oxidizing agents. }{ }^{10}\end{array}$ \\
\hline Reduced graphite oxide & $\begin{array}{l}\text { Reduced graphite oxide is produced by reducing } \\
\text { graphite oxide, thereby removing attached } \\
\text { oxygenated groups, allowing the honeycomb } \\
\text { lattice to be achieved - which restores } \\
\text { electrochemical properties. }{ }^{11}\end{array}$ \\
\hline Graphene & $\begin{array}{l}\text { Graphene sheets comprise of a } 2 \mathrm{D} \text { layer of } \mathrm{sp}^{2}- \\
\text { hybridized carbon atoms, arranged in a } \\
\text { hexagonal (honeycomb) lattice. }{ }^{9}\end{array}$ \\
\hline Graphene oxide & $\begin{array}{l}\text { Graphene oxide refers to single-atom layers of } \\
\text { carbon (graphene) with functional groups } \\
\text { containing oxygen attached. The oxygen groups } \\
\text { allow the molecular to become polar and } \\
\text { therefore soluble. }{ }^{12}\end{array}$ \\
\hline Reduced graphene oxide & $\begin{array}{l}\text { In order to create reduced graphene oxide, } \\
\text { graphene oxide can be reduced, often by thermal } \\
\text { mechanisms allowing for the removal of attached } \\
\text { oxygenated groups. }{ }^{12}\end{array}$ \\
\hline
\end{tabular}

Table 2. Features and antimicrobial efficiency of different graphene and graphite derivatives

\begin{tabular}{|c|c|c|c|c|c|}
\hline $\begin{array}{c}\text { Graphene/ } \\
\text { Metal }\end{array}$ & $\begin{array}{c}\text { Bacterial } \\
\text { strain }\end{array}$ & Methods used & Concentrations & $\begin{array}{c}\text { Suggested } \\
\text { mechanisms }\end{array}$ & References \\
\hline $\begin{array}{l}\text { Graphite Oxide } \\
(\mathrm{GtO})\end{array}$ & E. coli & $\begin{array}{l}\text { - Plate assay } \\
\text { method } \\
\text { - Shake flask } \\
\text { test in saline } \\
\text { - ZOI }\end{array}$ & & $\begin{array}{l}\text { - Membrane } \\
\text { stress or } \\
\text { Oxidative } \\
\text { stress: } \\
\text { production of }\end{array}$ & 13,14 \\
\hline
\end{tabular}


reactive oxygen

species (ROS)

\begin{tabular}{|c|c|c|c|c|c|}
\hline $\mathrm{GtO}-\mathrm{Ag}$ & E. coli & $\begin{array}{l}\text { Plate assay } \\
\text { method } \\
\text { - Shake flask } \\
\text { test in saline } \\
\text { - ZOI }\end{array}$ & $1.5 \mathrm{~mol} / \mathrm{L}$ & $\begin{array}{l}\text { Production of } \\
\text { ROS (harm } \\
\text { DNA/ proteins) }\end{array}$ & 13,15 \\
\hline $\mathrm{GtO}-\mathrm{Sand}$ & E. coli & $\begin{array}{l}\text { Plate assay } \\
\text { method } \\
\text { - Shake flask } \\
\text { test in saline } \\
\text { - ZOI }\end{array}$ & NA & $\begin{array}{l}\text { Membrane } \\
\text { stress }\end{array}$ & 13 \\
\hline Ag nanoparticle & E. coli & $\begin{array}{l}\text { Plate assay } \\
\text { method } \\
\text { - Shake flask } \\
\text { test in saline } \\
\text { - ZOI }\end{array}$ & $12 \mu \mathrm{g} / \mathrm{mL}$ & $\begin{array}{l}\text { Production of } \\
\text { ROS (harm } \\
\text { DNA/ proteins) }\end{array}$ & 13 \\
\hline \multirow[t]{4}{*}{$\begin{array}{l}\text { Graphene Oxide } \\
\text { (GO) }\end{array}$} & E. coli & \multirow[t]{4}{*}{$\begin{array}{l}\text { - Agar diffusion } \\
\text { method } \\
\text { - Viable count } \\
\text { - Scanning } \\
\text { electron } \\
\text { microscopy }\end{array}$} & $80 \mu \mathrm{g} / \mathrm{mL}$ & $\begin{array}{l}\text { Insertion/cutting } \\
\text { of cell } \\
\text { membrane and } \\
\text { extraction of } \\
\text { phospholipids }\end{array}$ & 16 \\
\hline & $\begin{array}{l}P . \\
\text { aeruginosa }\end{array}$ & & $150 \mu \mathrm{g} / \mathrm{mL}$ & ROS generation & 14 \\
\hline & S. aureus & & $\leq 10 \mu \mathrm{g} / \mathrm{mL}$ & $\begin{array}{l}\text { Wrapping of } \\
\text { bacterial cells }\end{array}$ & 14 \\
\hline & S. fecalis & & $\leq 10 \mu \mathrm{g} / \mathrm{mL}$ & $\begin{array}{l}\text { Membrane } \\
\text { stress }\end{array}$ & 14 \\
\hline \multirow[t]{3}{*}{$\begin{array}{l}\text { Reduced } \\
\text { (rGO) }\end{array}$} & E. coli & $\begin{array}{l}\text { - Cytotoxicity } \\
\text { test } \\
\text { - Cell viability } \\
\text { test } \\
\text { - Metabolic } \\
\text { activity assay }\end{array}$ & $100 \mu \mathrm{g} / \mathrm{mL}$ & $\begin{array}{l}\text { Cell membrane } \\
\text { damage due to } \\
\text { contact } \\
\text { interaction }\end{array}$ & 14,17 \\
\hline & $\begin{array}{l}P . \\
\text { aeruginosa }\end{array}$ & $\begin{array}{l}\text { - Cell viability } \\
\text { test }\end{array}$ & $150 \mu \mathrm{g} / \mathrm{mL}$ & NA & 18 \\
\hline & S. aureus & - MTT assay & & $\begin{array}{l}\text { Photothermal } \\
\text { ablation }\end{array}$ & 19 \\
\hline \multirow[t]{3}{*}{ GO-Ag } & E. coli & \multirow[t]{2}{*}{$\begin{array}{l}\text { - ZOI } \\
\text { - Colorimetric } \\
\text { methods } \\
\text { - UV visible } \\
\text { spectroscopy }\end{array}$} & $2,000 \mathrm{mg} / \mathrm{L}$ & $\begin{array}{l}\text { Cell wall } \\
\text { breakdown and } \\
\text { cytoplasm } \\
\text { release }\end{array}$ & 20 \\
\hline & $\begin{array}{l}P . \\
\text { aeruginosa }\end{array}$ & & NA & $\begin{array}{l}\text { Cell wall } \\
\text { breakdown and } \\
\text { cytoplasm } \\
\text { release }\end{array}$ & 20 \\
\hline & B. subtilis & $\begin{array}{l}\text { - ZOI } \\
\text { - MIC } \\
\text { - MBC } \\
\text { - Colorimetric } \\
\text { method for } \\
\text { kinetics }\end{array}$ & NA & $\begin{array}{lr}\text { Cell } & \text { wall } \\
\text { breakdown } & \text { and } \\
\text { cytoplasm } & \\
\text { release } & \end{array}$ & 15,21 \\
\hline
\end{tabular}




\begin{tabular}{|c|c|c|c|c|c|}
\hline \multirow[t]{3}{*}{$\mathrm{rGO}-\mathrm{Au}$} & S. aureus & \multirow{3}{*}{$\begin{array}{l}\text { - MIC } \\
- \text { MBC } \\
- \text { ZOI }\end{array}$} & $\mathrm{NA}$ & Oxidative stress & 22 \\
\hline & E. coli & & $2,000 \mathrm{mg} / \mathrm{L}$ & Oxidative stress & 22 \\
\hline & B. subtilis & & NA & Oxidative stress & 22 \\
\hline $\begin{array}{l}\text { Graphene oxide } \\
\text { - poly- } N \text { - } \\
\text { vinylcarbazole } \\
\text { (PVK-GO) } \\
\text { coating } \\
\end{array}$ & E. coli & $\begin{array}{l}\text { - Growth Curves } \\
\text { - } \\
\text { Epifluorescence } \\
\text { microscopy }\end{array}$ & $\begin{array}{l}3 \% \mathrm{GO} \text { on } \\
\text { surface }\end{array}$ & Oxidative stress & 23 \\
\hline $\begin{array}{l}\text { Graphene and } \\
\text { Poly- } N \text { - } \\
\text { vinylcarbazole } \\
\text { (PVK) }\end{array}$ & $\begin{array}{l}\text { E. coli } \\
\text { B. subtilis }\end{array}$ & $\begin{array}{l}\text {-AFM } \\
\text { - Metabolic } \\
\text { assay } \\
\text { - Live dead } \\
\text { assay }\end{array}$ & $97.3 \mathrm{w} / \mathrm{w} \%$ & NA & 24 \\
\hline \multirow{2}{*}{$\begin{array}{l}\text { Silver } \\
\text { nanoparticles in } \\
\text { combination } \\
\text { with graphene } \\
\text { oxide sheets }\end{array}$} & E. coli & \multirow{2}{*}{$\begin{array}{l}\text {-Agar well } \\
\text { diffusion assay } \\
\text {-ZOI }\end{array}$} & $60 \mu \mathrm{L}$ & \multirow{2}{*}{$\begin{array}{l}\text { ROS generation } \\
\text { and inhibition of } \\
\text { respiratory } \\
\text { enzymes }\end{array}$} & \multirow[t]{2}{*}{20} \\
\hline & $\begin{array}{l}P . \\
\text { aeruginosa }\end{array}$ & & $\begin{array}{l}26 \mathrm{~mm} \\
18 \mathrm{~mm}\end{array}$ & & \\
\hline \multirow[t]{3}{*}{$\begin{array}{l}\text { Graphene } \\
\text { nanosheets }\end{array}$} & $\begin{array}{l}\text { E. coli } \\
\text { Salmonella } \\
\text { typhimurium } \\
\end{array}$ & \multirow[t]{3}{*}{$-\mathrm{MIC}$} & $\begin{array}{l}1 \mu \mathrm{g} / \mathrm{mL} \\
1 \mu \mathrm{g} / \mathrm{mL}\end{array}$ & \multirow[t]{3}{*}{$\begin{array}{l}\text { Production of } \\
\text { ROS and lipid } \\
\text { peroxidation }\end{array}$} & \multirow[t]{3}{*}{25} \\
\hline & $\begin{array}{l}\text { Enterococcus } \\
\text { faecalis }\end{array}$ & & $8 \mu \mathrm{g} / \mathrm{mL}$ & & \\
\hline & B. subtilis & & $4 \mu \mathrm{g} / \mathrm{mL}$ & & \\
\hline $\begin{array}{l}\text { GO - Nitinol } \\
\text { surface coating }\end{array}$ & E. coli & $\begin{array}{l}\text {-Colony } \\
\text { forming unit } \\
\text { (CFU) counts } \\
\text {-Live/dead } \\
\text { fluorescent } \\
\text { staining } \\
\text {-SEM }\end{array}$ & $0.2 \mathrm{mg} / \mathrm{ml}$ & $\begin{array}{l}\text { ROS and sharp } \\
\text { edge plane } \\
\text { penetration of } \\
\text { cell membrane }\end{array}$ & 26 \\
\hline \multirow[t]{2}{*}{ GO nanosheets } & \multirow[t]{2}{*}{ E. coli } & -Viability assays & $\begin{array}{l}0.01 \mu \mathrm{m}^{2}-0.65 \\
\mu \mathrm{m}^{2}\end{array}$ & $\begin{array}{l}\text { ROS production } \\
\text { and higher } \\
\text { defect density } \\
\text { of smaller GO } \\
\text { particles }\end{array}$ & \multirow[t]{2}{*}{27} \\
\hline & & $\begin{array}{l}\text {-Suspension } \\
\text { assays }\end{array}$ & & Cell entrapment & \\
\hline Graphene film & $\begin{array}{l}\text { E. coli } \\
\text { S. aureus }\end{array}$ & $\begin{array}{l}\text {-CFU } \\
\text {-Live/dead } \\
\text { fluorescent } \\
\text { staining }\end{array}$ & $60 \mu 1 / \mathrm{mL}$ & $\begin{array}{l}\text { Loss of cell } \\
\text { membrane } \\
\text { integrity and } \\
\text { cell membrane } \\
\text { leakage }\end{array}$ & 28 \\
\hline \multirow{3}{*}{$\begin{array}{l}\text { Graphene oxide } \\
\text { nanowalls on } \\
\text { stainless steel }\end{array}$} & E. coli & - Cytotoxicity & NA & \multirow{2}{*}{$\begin{array}{l}\text { Loss of cell } \\
\text { membrane } \\
\text { integrity due to } \\
\text { sharp edge } \\
\text { penetration }\end{array}$} & \multirow[t]{2}{*}{29} \\
\hline & & $\begin{array}{l}\text {-RNA } \\
\text { measurement }\end{array}$ & $\begin{array}{l}30 \mathrm{ng} / \mathrm{ML} \\
38 \mathrm{ng} / \mathrm{mL}\end{array}$ & & \\
\hline & E. coli & & $\mathrm{NA}$ & & 29 \\
\hline
\end{tabular}




\begin{tabular}{|c|c|c|c|c|c|}
\hline $\begin{array}{l}\text { rGO - stainless } \\
\text { steel }\end{array}$ & S. aureus & $\begin{array}{l}\text {-Cytotoxicity } \\
\text { test } \\
\text {-RNA } \\
\text { measurement }\end{array}$ & $\begin{array}{l}43 \mathrm{ng} / \mathrm{mL} \\
56 \mathrm{ng} / \mathrm{mL}\end{array}$ & $\begin{array}{l}\text { Loss of cell } \\
\text { membrane } \\
\text { integrity due to } \\
\text { sharp edge } \\
\text { penetration }\end{array}$ & \\
\hline $\begin{array}{l}\text { GO nanosheets - } \\
\text { paper surface } \\
\text { coatings }\end{array}$ & E. coli & $\begin{array}{l}\text {-Luciferase-based } \\
\text { ATP assay kit } \\
\text {-TEM }\end{array}$ & $\begin{array}{l}85 \mu \mathrm{g} / \mathrm{mL} \\
\mathrm{NA}\end{array}$ & $\begin{array}{l}\text { Loss of cell } \\
\text { membrane } \\
\text { integrity }\end{array}$ & 17 \\
\hline
\end{tabular}

\section{Graphite}

Graphite is one of the oldest and most widely used of the carbon-based materials. ${ }^{30}$ Graphite is routinely used as a starting material in the production of a variety of carbon-based nanomaterials including fullerenes, nanodiamonds, single and multi-walled nanotubes and the synthesis of graphene. ${ }^{31}$ Graphite has been used in a variety of biomedical applications ${ }^{32,33}$ including drug delivery, ${ }^{34,35,36}$ photothermal anticancer activity $37,38,39$, biosensors, biofunctionalisation ${ }^{34}$ disease diagnostics ${ }^{40,41,42}$ and antimicrobial therapies. ${ }^{43}$

The antimicrobial activity of graphite has been demonstrated, whereby the interaction between graphite nanoplatelets and Pseudomonas aeruginosa (which can cause chronic infections in the lungs of patients with cystic fibrosis) was investigated. The results of a bacterial cell viability assay, performed after $5 \mathrm{~h}$ of incubation with graphite nanoplatelets, demonstrated a viability loss of up to $69.5 \%$, as opposed to the control with no graphite nanoplatelets. ${ }^{44}$ Work in our laboratories has demonstrated that following minimal bactericidal concentration assays using particulate compounds, when tested against Gram negative Escherichia coli, graphite demonstrated greater antimicrobial efficacy than graphene and was comparable with the antimicrobial efficacy of zinc oxide (Fig.1). However against Gram positive $S$. aureus, although graphite again demonstrated greater antimicrobial activity than graphene, its antimicrobial efficacy was not greater than that of zinc oxide. This may be explained in part due to the differences in the chemical composition of bacterial cell walls of Gram negative and Gram positive bacteria. 


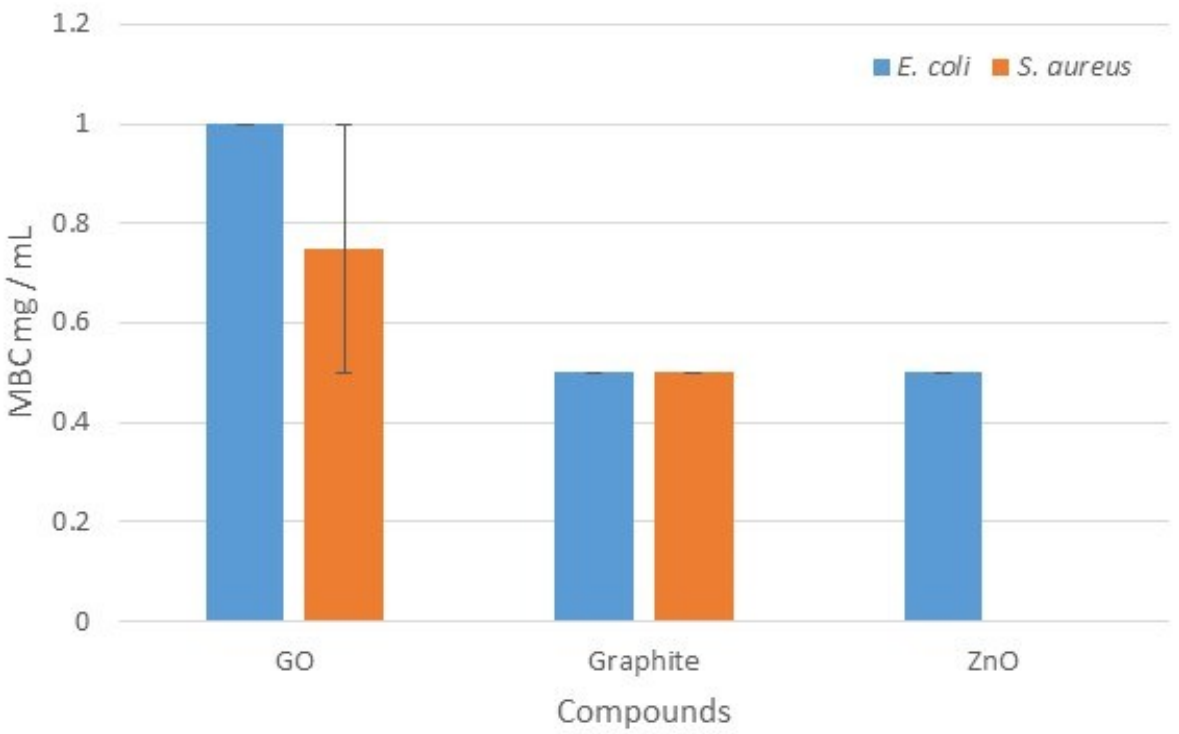

Fig. 1. Minimal bactericidal concentrations (MBC) of graphite, graphene oxide and zinc oxide demonstrating that the graphite demonstrates antimicrobial efficacy against $E$. coli and S. aureus (Work courtesy of Daniel Brown, MMU, UK).

The use of graphite as an antimicrobial surface coating is in its infancy, however, early results using carbon thin films have been promising. ${ }^{45}$ In a study whereby carbon thin films (previously known as graphite) were used as a antimicrobial coatings on a polyethylene terephthalate (PET) surface, the results demonstrated that the carbon thin films reduced bacterial adherence capabilities by $65 \%$ and 86 $\%$ for both S. aureus and Staphylococcus epidermidis, respectively. ${ }^{45}$

Shteynle, (2012) compared the absorbency and fluid retention of two variants of nanostructured graphite wound dressings and a variety of "gold standard" wound dressings. The nanostructured graphite wound dressings demonstrated the greatest adsorption potential, but no antimicrobial testing was carried out. The nanostructured graphite wound dressings were able to adsorb the wound exudate due to a variety of mechanisms including covalent bonding, a system of numerous interweaving fibres that produced a high surface area ${ }^{46}$, and a matrix consisting of strong fluoride oxidisers, resulting in large quantities of free radicals. Furthermore, these oxidisers added oxygenated species to the surface of the graphite, increasing its hydrophobicity. ${ }^{47}$ It has been reported that the absence of excessive wound exudate (i.e. by adsorption), can reduce the risk of nosocomial/opportunistic infection by making the conditions for the commensal microflora less than favourable. ${ }^{48}$ Graphite is proposed to be able to act as an antimicrobial in a variety of ways, including physiochemical responses leading to membrane 
stress, sharp nanosheets which result in disruption of the cell membrane and via the production of reactive oxygen species, due to the oxidation of glutathione which acts as a redox mediator in bacterial cells. $^{49}$

\section{Graphite oxide}

Graphite oxide is produced via the oxidation of natural graphite. Characterisation studies identify graphite oxide as a lamellar solid containing phenolic, carboxyl and epoxide groups. This makes graphite oxide hydrophilic, with the production of monolayer colloidal dispersions upon interaction with water. ${ }^{50}$ Delamination of graphite oxide solids often forms the basis for the synthesis of graphite oxide nanomaterials. Graphite oxide has unique properties, namely enhanced electrochemical activities in the form of capacitor materials due to the presence of hydroxyl, epoxy and carbonyl groups ${ }^{51,52,53}$. Graphite oxide is often only ever intended to be used as a by-product in the synthesis of graphene-based nanosheets produced by the chemical reduction of exfoliated graphite oxide and the antimicrobial efficacy of graphite oxide has yet to be fully documented. However, in one study ${ }^{54}$, the antimicrobial efficacy of graphite oxide was compared to that of other carbon-based materials (graphite, graphene oxide and reduced graphene oxide) against $E$. coli. The results showed that graphene oxide had the greatest antimicrobial activity (inactivating $69 \%$ of bacterial cells after 2 hours of incubation) followed by reduced graphene oxide, graphite followed by graphite oxide which inactivated $15 \%$ of bacterial cells at the same dispersion concentration. ${ }^{54}$ Das et al, (2011) synthesised a silver nanoparticle and graphite oxide nanosheet composite. Using X-ray diffraction and transmission electron microscopy, the results indicated that the silver nanoparticles decorated the graphite oxide sheets and following antimicrobial testing of the nanosheets, antibacterial activity was indicated against $E$. coli and $P$. aeruginosa using zone of inhibition assys. ${ }^{20}$ The underlying antimicrobial mechanism of graphite oxide remains unclear, however its large surface area could allow for cell wrapping. Cell wrapping can be attributed to the hydrophobicity of graphene materials, since the graphene sheets are hydrophobic. This can lead to the phospholipid bilayers of microorganisms (in direct contact with the graphene) to become inversed, therefore leading to the loss of membrane integrity and cell lysis ${ }^{55}$. Other antimicrobial mechanisms for graphite oxide include its oxygen containing surface functionalities such as carboxylic, 
carbonyl, hydroxyl and epoxide groups as well as its increased water solubility which provides a basis for ion or nanoparticle intercalation, which can in turn have a detrimental effect on bacterial cells. ${ }^{56}$

\section{Reduced Graphite Oxide}

Reduced graphite oxide is often used as a starting product in the production of graphene. Graphite oxide is reduced by a two-step system, with the first step being the removal of oxygen groups via the use of sodium tetrahydridoborate followed by the second step which uses concentrated sulphuric acid to dehydrate and therefore restore the chemical structure ${ }^{57}$. Research into reduced graphite oxide as a standalone material is relatively novel, however due to its reported unique electrochemical properties (as demonstrated by all graphene-based materials), an increasing amount of research has been recently targeted in this area - especially with the application of reduced graphite oxide as a material for use in supercapacitors and batteries. ${ }^{58,59}$ However research into the antimicrobial efficacy has not yet been fully elucidated.

In 2011, Dai et al., produced a novel reduced graphite oxide-silver nanocomposite which showed a synergistic antimicrobial effect. The reduced graphite alone displayed no apparent antimicrobial effect however, when used in combination with silver ions an improved synergistic antimicrobial effect was seen. ${ }^{60}$ The authors hypothesized that the reduced graphite oxide acted as a supporting structure, whilst the silver ions possessed the overall antimicrobial ability ${ }^{60}$ This was emphasised by Gerasymchuk et al., (2016) who carried out antimicrobial testing on a reduced graphite oxide, silver nanoparticle and bis(lysinato)zirconium(IV) phthalocyanine complexes. ${ }^{61}$ The complex was tested for its antimicrobial efficacy against $S$. aureus, E. coli and $P$. aeruginosa. The results showed a prolonged synergistic antimicrobial effect after near-infrared irradiation, with a four-fold decrease observed in the Gramnegative strains (P. aeruginosa and E. coli) viable cells. ${ }^{61}$ The authors suggested that the complex should be tested as an antimicrobial surface coating for use in the field of dentistry or as a wound dressing due to its long lasting properties ${ }^{61}$. Therefore, the use of reduced graphite oxide in combination with another antimicrobial agent could potentially demonstrate a synergistically antimicrobial effect.

\section{Graphene}

Since the discovery of graphene by Geim and Novoselov in 2006/7, research into this material and field has increased exponentially ${ }^{62}$. Graphene is a one-layer atom thick sheet of hexagonally 
arranged carbon. In recent years, graphene has attracted a lot of interest in a wide variety of industries, due to its unique properties such as excellent thermal conductivity (up to $5,000 \mathrm{~W} \mathrm{~m}^{-1} \mathrm{~K}^{-1}$ ), electrical conductivity, high electron mobility of up to $200,000 \mathrm{~cm}^{2} \mathrm{~V}^{-1} \mathrm{~s}^{-1}$, permeability to gases, excellent tensile strength $\left(42 \mathrm{~N} \mathrm{~m}^{-1}\right)$, and its high surface area $\left(2630 \mathrm{~m}^{2} \mathrm{~g}^{-1}\right)^{63}$. Graphene has a variety of proposed antimicrobial mechanisms including damage due to physiochemical interactions (hydrophobicity), or due to physical interactions (size / sharp edges) (Fig. 2). The lateral size of graphene-materials is essential when determining the antimicrobial activity, this is because lateral size can influence the adsorption, dispersibility and the structure, including sharp edges - which are crucial for antimicrobial physiochemical interactions between the graphene-materials and microorganisms.

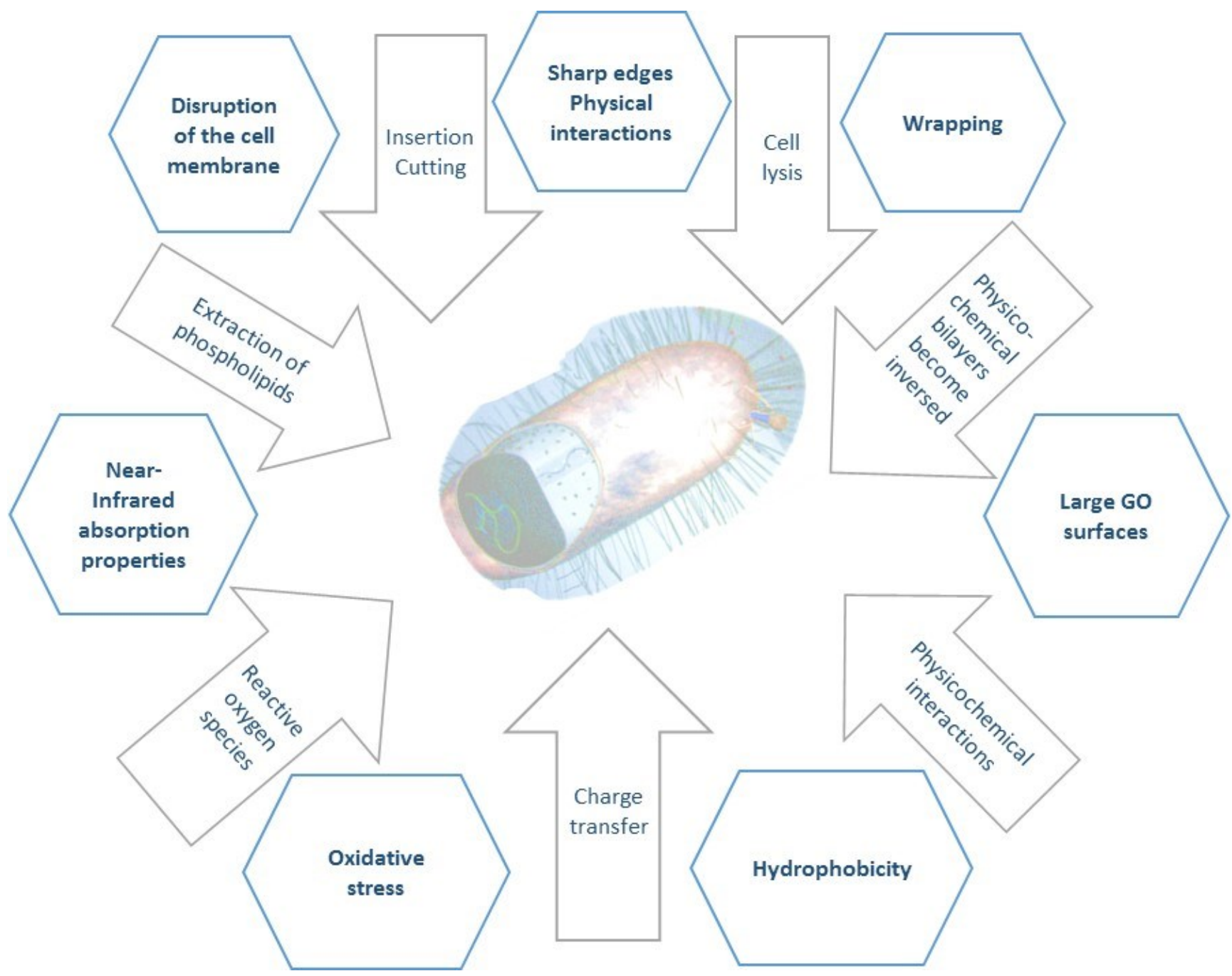

Fig. 2. Schematic illustration of the potential mechanisms of antibacterial activity of the graphites / graphenes (Microbial figure courtesy of Dr Lucia Cabellero, MMU, UK). 
Another proposed antimicrobial action proposed to be demonstrated by larger molecules of graphene materials is cell wrapping ${ }^{64}$. Dallavalle et al., (2015) investigated the relationship between graphene material lateral size and antimicrobial mechanisms ${ }^{65}$. It was demonstrated that graphene material, less than $5.2 \mathrm{~nm}$ in size, had a predominant physical effect against microorganisms leading to cell lysis by protrusion of cell membranes, which is in turn attributed to the sharp edges of graphene materials. ${ }^{65}$ On the other hand, larger graphene molecules (more than $5.2 \mathrm{~nm}$ ) act by reducing the microbial activity / cell viability of bacterial microorganisms through "wrapping" process, without affecting the cell's integrity / shape. This was demonstrated by measuring nicotinamide adenine dinucleotide hydrogen and/or nicotinamide adenine dinucleotide phosphate, in a cellular metabolic assay $^{30}$.

Large area monolayer graphene foams, have been used as a surface coating of copper conductors, and demonstrated promising properties against both Staphylococcus aureus and Escherichia coli. However, when the same bacteria were tested on a graphene-coated silicon dioxide insulator, although antimicrobial activity was observed, the morphology of the bacteria remained the same, therefore, charge transfer may be another mechanism of antimicrobial activity. ${ }^{66}$ This charge transfer mechanism was described in further detail by Bykkam et al., (2015) which showed graphene foams coated with zinc oxide nanoparticles irradiated high photon energy levels, leading to the transfer of electrons from the valence band to the conduction band of the product material. This was shown to produce holes in the valence band, which were able to react with hydroxyl groups and absorbed water to create hydroxyl radicals (-OH). Electrons trapped in the conduction band by the presence of oxygen were shown to produce superoxide radical ions $\left(\bullet \mathrm{O}^{-2}\right)$, whilst hydrogen peroxide was generated by the combination of the electron pair hole, the production of reactive oxygen species (ROS) then exhibited a detrimental effect on the bacterial cells ${ }^{67}$.

Akhavan and Ghaderi, (2010), investigated the antimicrobial activity of graphene layers against both Gram positive (S. aureus) and Gram negative bacteria (E. coli), however the results demonstrated a greater antimicrobial effect against $S$. aureus, possibly due to lack of an outer membrane ${ }^{68}$. However, antimicrobial activity was also demonstrated when zinc nanoparticles were imbedded into graphene sheets producing zones of inhibition against Gram negative Salmonella typhi and Gram negative $E$. 
coli $^{69}$ In one study, a novel graphene based silver/ hydroxyapatite / graphene (Ag / HAP / Gr) composite surface coating was produced by electrophoretic deposition (EPD), and the antimicrobial efficacy was tested against both $S$. aureus and E. coli. The results showed that after one hour bacterial growth had been inhibited by $72.9 \%$ and $68.4 \%$, respectively, and after 24 the samples did not contain any viable cells, thus suggesting that the antimicrobial activity was effective against both planktonic and biofilmforming strains of bacteria ${ }^{70}$. Due to graphene's low cytotoxic activity against human cells and excellent bacterial toxicity, it is an ideal candidate for application with biomaterials. When graphene was used as a surface coating of poly(N-vinylcarbazole) (PVK), results showed inhibition of up to $80 \%$ of biofilm growth, after 24 hour of incubation with E. coli and Bacillus subtilis, compared against a NIH 3T3 (mouse) cell line where over $80 \%$ of the cells were viable after 24 hours. ${ }^{71}$ In our laboratories, when 3D graphene foams have been combined with metal ions, using zone of inhibition assays, antimicrobial activity was demonstrated to be increased against Gram positive bacteria (Fig. 3).

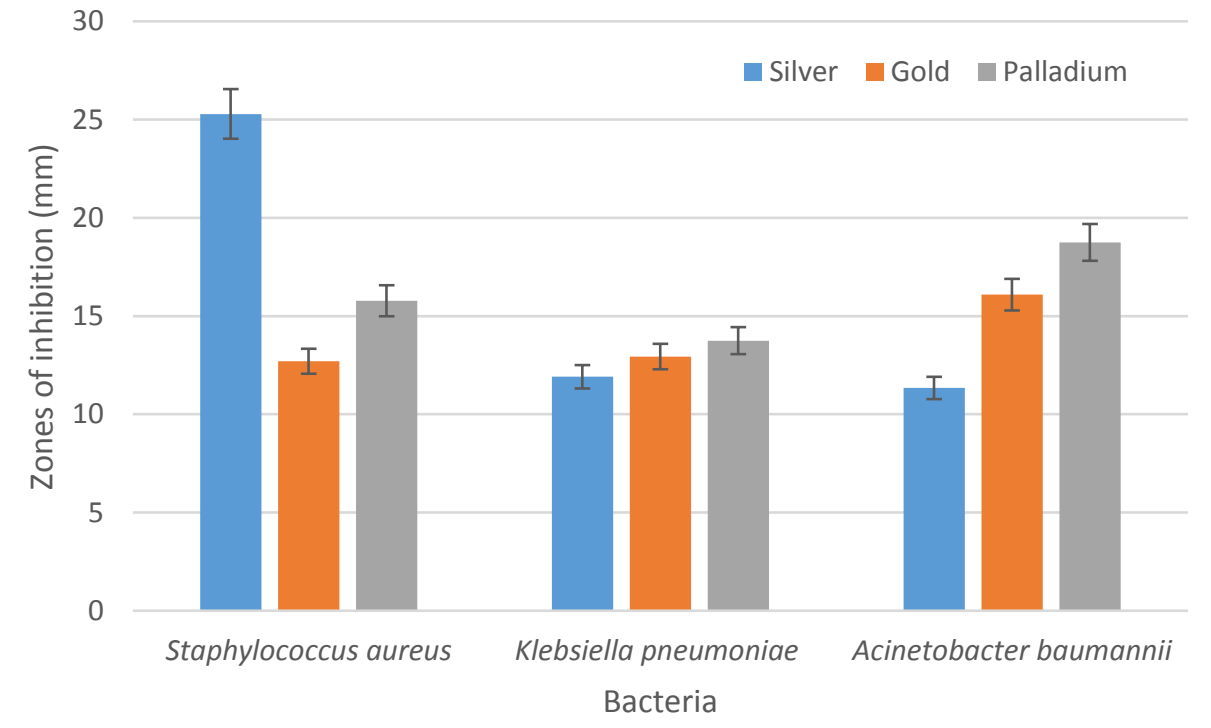

Fig. 3. Antimicrobial activity of few layer 3D freestanding graphene foams doped with metals

Antibacterial activity was also demonstrated against the more recalcitrant Gram negative Klebsiella pneumoniae and Acinetobacter baumannii. Further, our work demonstrated that on a 3D graphene foam substrate that has been soaked in a gallium compound, the physiological structure of the bacterial cells becomes altered due to cellular damaged (Fig. 4). 

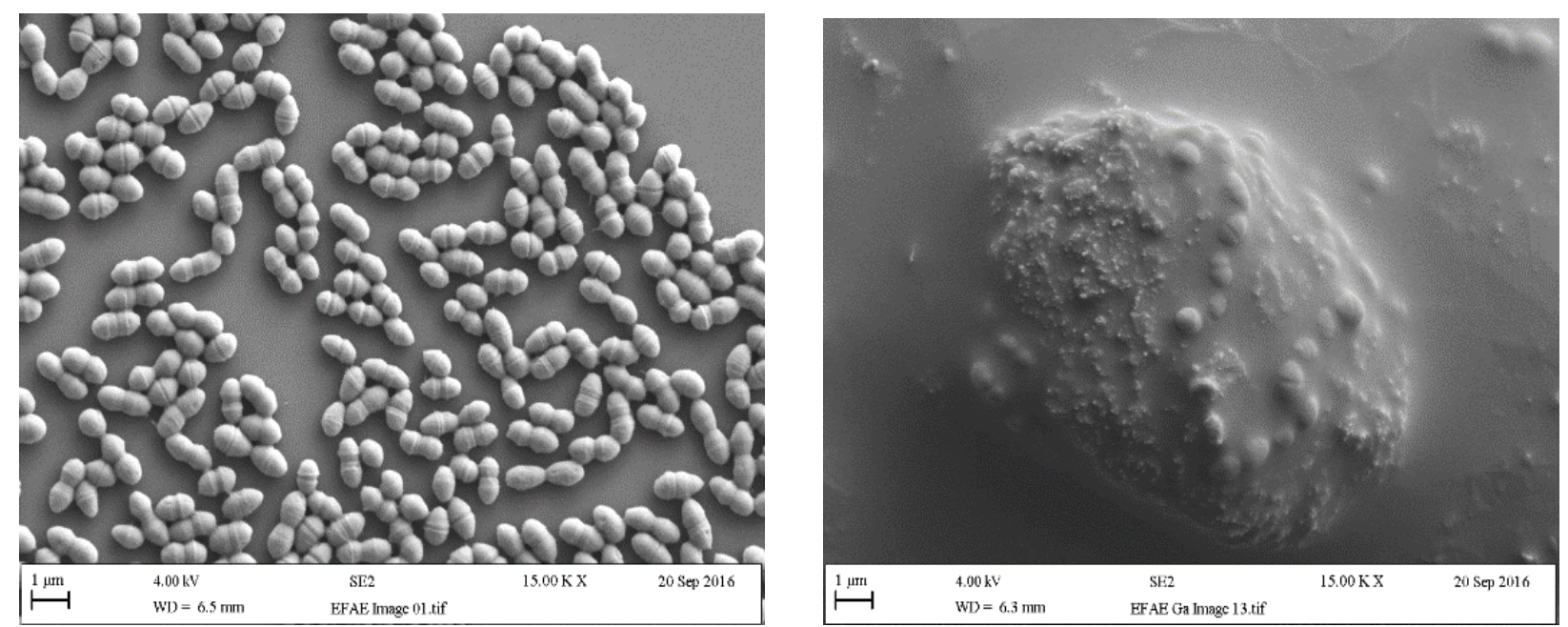

Fig. 4. a) Enterococcus faecium cell structure b) Enterococcus faecium following inoculation onto a 3D graphene / gallium structure (Images courtesy Anthony Slate and Dr Grace Crowther, MMU, UK).

Therefore, with further research, graphene could have the potential to be used as a surface coating for both equipment (i.e. nosocomial setting) and/or in wound dressings, due to its variety of antimicrobial mechanisms, including physiochemical interactions such as cell wall penetration, and cell wrapping depending on the lateral size of the graphene particle.

\section{Graphene Oxide}

Much alike graphene, graphene oxide is a 2D-nanomaterial with promising applications in a variety of fields including polymer composites, electrochemical appliances (i.e. electrodes), sensors and biomedical applications $^{9}$ due to its excellent electrical, thermal and mechanical properties ${ }^{12}$. Unlike graphene, graphene oxide is hydrophilic due to the oxygen containing groups, allowing it to solubilise in water. ${ }^{10}$ Graphene oxide is a promising material for the development of antimicrobial surface coating, due to its reported excellent contact-based antimicrobial activity; however the exact mechanisms are yet to be fully elucidated. ${ }^{11}$ Graphene oxide is reported to have demonstrated broad-spectrum antimicrobial activity against both bacteria and fungi, including resistant strains. ${ }^{13}$ Graphene oxide has also demonstrated broad spectrum antiviral activity; it was shown to significantly reduce both pseudorabies virus (PRV) and porcine epidemic diarrhoea virus (PEDV), leading to a two log reduction of viral titres. ${ }^{72}$ This antimicrobial activity has been attributed to the introduction of oxygen-containing groups present in graphene oxide. It has been shown that altering the surface properties of graphene oxide, such as the edge planes, can dramatically improve antimicrobial activity, leading to a marked 
improvement in both amphipathy (important for the wrapping mechanism) and physiochemical effects. $^{68}$

Since graphene oxide is water-soluble it has properties that allow for high drug loading and miscibility with polymers, effectively allowing it to be moulded into any desired shap ${ }^{14}$. Bitounis et al., (2013) reported that in a study investigating the antimicrobial effect of graphene based materials, that graphene oxide demonstrated the greatest antimicrobial efficacy followed by reduced graphene oxide, and this was suggested to be due to the production of ROS which led to oxidative stress, leading to more severe membrane damage and therefore loss of cell membrane integrity ${ }^{73}$.

A decrease in graphene oxide sheet size $\left(0.65 \mu \mathrm{m}^{2}\right.$ to $\left.0.01 \mu \mathrm{m}^{2}\right)$, when tested against $E$. coli, also demonstrated a direct correlation of increased antimicrobial activity, due to physiochemical interactions ${ }^{11}$. In contrast, when using a suspension assay, the larger the graphene oxide sheets, the more effective became the antimicrobial activity. This was suggested to be due to cell entrapment, i.e. wrapping, with complete inactivation observed with the $0.65 \mu \mathrm{m}^{2}$ graphene oxide sheets after 3 hours of exposure. However cell inactivation due to the cell entrapment mechanism could be reversed, when separating the graphene oxide sheets by sonication. ${ }^{11}$ Graphene oxide nanosheets have demonstrated strong antimicrobial properties when used in conjunction with thin-film composites as a surface coating. Graphene oxide nanosheets were irreversible attached via amide coupling of carboxyl groups present on both graphene oxide and a polyamide active layer. Microbiological testing of this surface coating against $E$. coli showed $65 \%$ bacterial inactivation after 1 hour of incubation ${ }^{74}$. In another study, a graphene oxide-iron oxide nanoparticle-silver nanoparticle (GO-IONP-Ag) complex was evaluated as a surface coating. The results showed that the composite was more effective than silver nanoparticles alone, showing a marked increase in antimicrobial activity against both Gram-positive (S. aureus) and Gram-negative (E. coli) bacterial strains. This synergistic ability was thought to be due to light being absorbed by the GO demonstrated a synergistic response, resulting in the photo-thermal killing of the bacteria $^{75}$. Faria et al., (2014) also used graphene oxide in combination with silver nanoparticles as a surface coating, which resulted in $100 \%$ growth inhibition of Pseudomonas aeruginosa, with a minimum inhibitory concentration (MIC) ranging between $2.5-5.0 \mathrm{mg} / \mathrm{L}^{76}$. Work by Whitehead et al., (2017) has demonstrated that when silver-graphene oxide (AgGO) or zincoxide-graphene oxide 
(ZnOGO) complexes were tested for their antimicrobial activity against four prominent bacteria which have all demonstrated increased multidrug resistance (E. coli, Methicillin Resistant S. aureus (MRSA), Enterococcus faecium and Klebsiella pneumoniae) that AgGO was the most effective antimicrobial. The addition of $\mathrm{Ag}$ enhanced the activity of GO against the bacteria tested, including the generally recalcitrant K. pneumoniae and Enterococcus faecium. Zhao et al., (2016) developed a gelatinfunctionised graphene oxide coating which was impregnated onto a nitinol substrate. The results showed both strong antimicrobial activity against $E$. coli and excellent biocompatibility ${ }^{26}$. Therefore it can be evidenced that alterations to the graphene oxides surface properties as well as its characteristic functional groups (leading to the production of ROS) allows graphene oxide to interact with microorganisms in a dual approach, therefore suggesting an explanation towards the prolific antimicrobial activity demonstrated.

\section{Reduced Graphene Oxide}

In order to obtain reduced graphene oxide (also known as functionalised graphene or reduced graphene), removal of oxygen-containing groups is vital, with the end goal of the reduction protocol being to produce graphene-like materials with similar properties to graphene ${ }^{77}$. Reduction of graphene oxide can be undertaken by a variety of mechanisms including, mechanical / thermal exfoliation, epitaxial growth and chemical vapour deposition. ${ }^{78,79}$

Reduced graphene oxide has demonstrated a vast array of potential applications including electrochemical materials, ${ }^{15}$ photocatalysis, ${ }^{80}$ industrial lubricants and corrosion protection. ${ }^{81}$ The antimicrobial activity of graphene oxide has yet to be fully elucidated, however, studies so far have demonstrated positive results with the potential application of reduced graphene oxide to be used as a viable antimicrobial agent. ${ }^{79}$ In one study, a biocompatible reduced graphene oxide-silver nano-hybrid was prepared and tested as an antimicrobial topical agent i.e. as a surface coating for dressings and bandages. The results found that excellent cytocompatibility was observed towards peripheral blood mononuclear cells and mammalian red blood cells whilst antimicrobial assays against S. aureus, E. coli and Candida albicans showed synergistic antimicrobial activity compared to reduced graphene oxide and silver nanoparticles as individual antimicrobial therapies ${ }^{82}$. This biocompatibility of reduced graphene oxide has also been described when used in combination with calcium silicate which plays an 
important role in bone tissue engineering. The use of a calcium silicate and reduced graphene oxide composite increased the fracture toughness by $123 \%$ without negatively effecting the attachment of human osteoblast cells (hFOB) $)^{83}$.

Synergistic antibacterial activity has been demonstrated between reduced graphene oxide and boron-doped diamond anodes, with the results showing a reduction of $0.7 \log$ of E. coli after $20 \mathrm{~min}$ of incubation with graphene oxide. However, $100 \%$ inactivation of $E$. coli growth was demonstrated when reduced graphene oxide was tested in combination with a three dimensional electrochemical system ${ }^{79}$. Previous studies proved that hydroxyl radicals played a pivotal role in boron doped diamond electrochemical disinfection, and it was hypothesised that the reduced graphene oxide led to an expansion in the electrode area and therefore generated more hydroxyl radicals ${ }^{84}$. Reduced graphene oxide nanosheets doped onto titanium dioxide thin films showed improved antimicrobial activity against $E$. coli under solar light radiation (by $60 \%$ ) after 0.5 hours. The thin films were demonstrated to be chemically stable and it was suggested that they could be used as an antimicrobial surface coating for hospital equipment, thus potentially reducing the transmission of AMR and other microorganisms. ${ }^{85}$ Evidence suggests that the main mechanism of antimicrobial activity produced by reduced graphene oxide is due to the production of reactive oxygen species. This was shown to be the case in one study, where the exposure of graphene oxide and reduced graphene oxide to $P$. aeruginosa induced significant amounts of superoxide radical anions, leading to the loss of cell viability. ${ }^{16}$

\section{Non-carbon based 2D nanomaterials}

Other non-carbon based, 2D-nanomaterials with potential applications in antimicrobial surface coatings include boron nitrite, tungsten dioxide and molybdenum disulphide. However, these surfaces have not been investigated in great depth for their antimicrobial activity.

\section{Boron Nitride}

Boron nitride commonly exists in a layered structure of hexagonal honeycombs comprised of equal amounts of boron and nitrogen atoms. These layers are held together by van der Waals forces, with the nitrogen atoms directly above the boron atoms. ${ }^{17}$ Due to its similarity to graphene, both in terms of structure and properties it is often referred to as "white graphene" ${ }^{86}$. This similarity has been observed by a number of studies, with one example being the use of boron nitride as a electrochemical 
dopamine biosensor. ${ }^{87}$ In recent years, research with boron nitride has shown antimicrobial activity related to the 2D-nanomaterial. It was demonstrated that aqueous dispersions of boron nitride nanotubes exhibited little antimicrobial activity against E. coli and S. aureus. However, when coated in combination with polyethyleneimine, the boron nitride nanotubes exhibited a significant synergistic antimicrobial activity against $E$. coli and $S$. aureus, with the authors suggesting the potential application of boron nitride nanotubes as surface coatings for use in water purification and food packaging systems. ${ }^{88}$

\section{Tungsten Diselenide}

Another 2D-nanomaterial with great potential is tungsten diselenide $\left(\mathrm{Se}_{2} \mathrm{~W}\right)$. When in crystalline monolayers it is found to act as a promising emitter of light at around $750 \mathrm{~nm} .{ }^{89}$ Tungsten diselenide is a two dimensional metal dishalcogenide, with a semiconducting nature. ${ }^{90}$ These properties allow WSe $\mathrm{W}_{2}$ to act as a photo-catalyst, leading to the production of hydrogen, which result in the generation of ROS which have the ability to cause damage to a wide array of microorganisms by a variety of mechanisms. ${ }^{91,92}$ The research into the antimicrobial effect of tungsten diselenide is in its infancy, however recent studies have demonstrated impressive antimicrobial efficacy. ${ }^{90,93}$ One study demonstrated the antimicrobial activity of selenium nanoparticles when used as a surface coasting in conjunction with polymeric medical devices. ${ }^{94}$ In another study, tungsten diselenide in combination with single-stranded DNA (ssDNA) and the antimicrobial efficacy of the $\mathrm{WSe}_{2}$-ssDNA nanosheets was evaluated against $E$. coli. The results demonstrated a greater antimicrobial effect compared to the use of graphene oxide. ${ }^{93}$ Research into $\mathrm{Se}_{2} \mathrm{~W}$ may show potential for this to be developed into an alternative antimicrobial surface coating. ${ }^{95}$

\section{Molybdenum Disulfide}

Molybdenum disulphide $\left(\mathrm{MoS}_{2}\right)$ which is also a two dimensional metal dishalcogenide, is the principle natural source of molybdenum, and is mainly obtained as a secondary product from the mining of copper. Anisotropic properties of $\mathrm{MoS}_{2}$ which arise due to its laminar nature (similar to graphite), allow $\mathrm{MoS}_{2}$ to be used in a variety of applications including industrial lubricants, catalysts and electrical energy storage products. ${ }^{18}$ 
The antimicrobial efficacy of 2D chemically exfoliated $\mathrm{MoS}_{2}$ sheets was evaluated by Yang et al., (2014) against E. coli. The results demonstrated that an MIC of $2.5 \mu \mathrm{g} / \mathrm{mL}$ was inhibitory to the bacteria and this antimicrobial activity was attributed to the production of ROS, particularly due to glutathione oxidation which showed a time and concentration dependent trend. It was speculated that the accumulation of ROS led to both membrane and oxidative stress, and eventually loss of cell membrane integrity and death ${ }^{96}$. It has been further suggested that the $\mathrm{MoS}_{2}$ showed a greater amount of antimicrobial activity towards Gram-positive bacteria. ${ }^{97,98}$ In agreement with this, work in our laboratories has demonstrated that molybdenum disulphide surfaces do have some antimicrobial activity against Gram positive (S. aureus) and Gram negative (E.coli) biofilms (Fig. 5). Biofilm inhibition has also been demonstrated by molybdenum disulphide by others. In a study, P. aeruginosa biofilms were grown with molybdenum disulphide at a concentration of $150 \mu \mathrm{g} / \mathrm{mL}$ and the results showed a decrease in the biofilm growth of up to $40 \%$, in addition to shrinkage in biofilm depth after treatment ${ }^{89}$. These results may prove to be extremely important given the recalcitrant nature of biofilms.

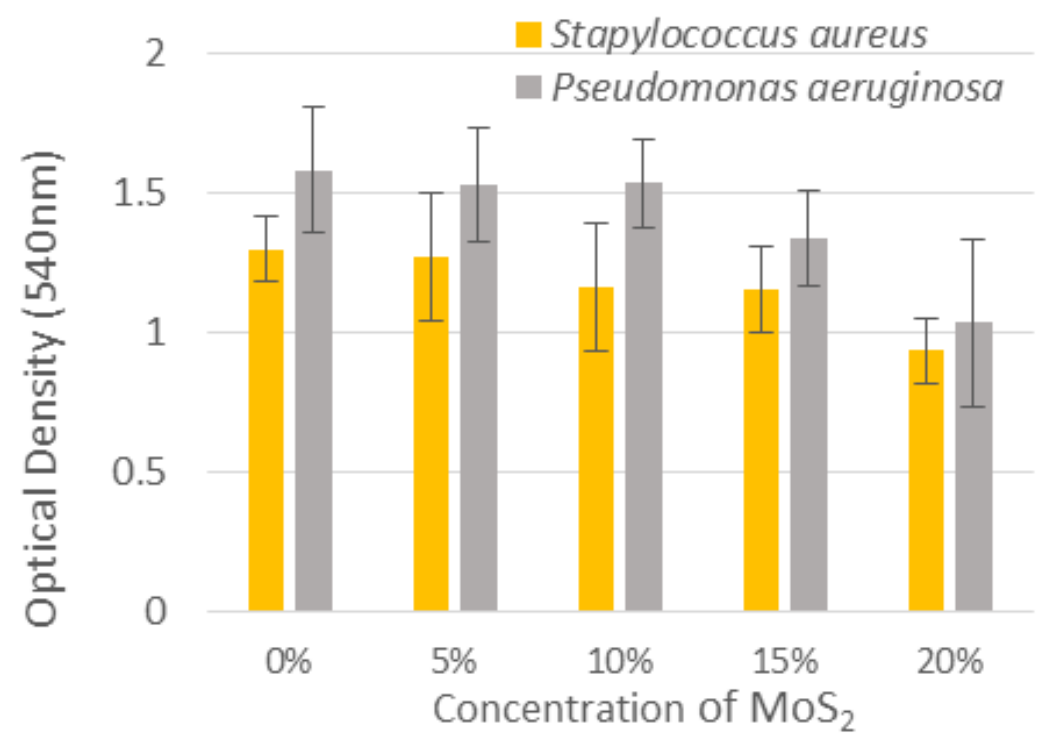

Fig. 5. Antimicrobial effect of $\mathrm{MoS}_{2}$ surfaces evaluated against biofilms (Work courtesy of Moshin Amin, MMU, UK).

\section{Conclusion}


Throughout this chapter, the antimicrobial potential and applications for the use of 2D-nanomaterials, especially in the case of potential antimicrobial surface coatings has been discussed. Although research into 2D-nanomaterials as surface coatings is in its infancy, research in this area is rapidly progressing. However, more research is needed in order to fully elucidate and characterise all the mechanisms of antimicrobial activity of such materials. This would allow researchers to be able to modify the nanomaterials structures / properties in order to make them more potent and effective as antimicrobial agents. In addition to using these $2 \mathrm{D}$ nanomaterials as stand-alone antimicrobial interventions, there is significant interest in utilising these 2D nanomaterials in combinations with other molecules, functional groups and metals. Combinations of such chemical moieties may result in surfaces that demonstrate synergistic antimicrobial effects, that may have the potential to reduce the transmission of nosocomial infections. This in turn may decrease the current burden which is currently placed upon conventional bacterial treatments such as antibiotics. The current literature highlights the huge potential these nanomaterials could have in order to reduce the transmission of antimicrobial resistant bacteria.

\section{Acknowledgements}

The authors would like to thank Dr Lucia Cabellero, Dr Grace Crowther, Moshin Amin and Daniel Brown for their contributions of the Figures -towards this work.

\section{References}

1. C. L. Ventola, Pharmacy and Therapeutics, 2015, 40, 277-283.

2. J. G. Bartlett, D. N. Gilbert and B. Spellberg, Clinical and Infectious Diseases, 2013, 56, 1445 1450.

3. H. Ochman, J. G. Lawrence and E. A. Groisman, Nature, 2000, 405, 299-304.

4. J. Davies and D. Davies, Microbiology and Molecular Biology Reviews : MMBR, 2010, 74, 417-433.

5. J. N. Pendleton, S.P. Gorman, B.F. Gilmore, Expert Review of Anti Infective Therapy 2013, 11, 297-308.

6. World Health Organisation (2014). http://apps.who.int/iris/bitstream/10665/112642/1/978241564748_eng.pdf 
7. N. Wu, L. He, P. Cui, W. Wang, Y. Yuan, S. Liu, T. Xu, S. Zhang, J. Wu, W. Zhang and Y. Zhang, Frontiers Microbiology 2015, 6, 1003.

8. P. Chen, A. K. Seth, J. J. Abercrombie, T. A. Mustoe and K. P. Leung, Antimicrobial Agents and Chemotherapy, 2014, 58, 1208-1213.

9. O. C. Compton and S. T. Nguyen, Small, 2010, 6, 711-723.

10. H. He, J. Klinowski, M. Forster and A. Lerf, Chemical Physics Letters, 1998, 287, 53-56.

11. M. Eluyemi, M. Eleruja, A. Adedeji, B. Olofinjana, O. Fasakin, O. Akinwunmi, O. Ilori, A. Famojuro, S. Ayinde and E. Ajayi, Graphene, 2016, 5, 143.

12. C. H. An Wong, Nanoscale, 2012, 4, 4972.

13. I. Sheets, H. Holail, Z. Olama, A. Kabbani and M. Hines, International Journal of Current Microbiology and Applied Sciences 2013, 2, 1-11.

14. T.H. Liu, Zeng, M. Hofmann, E. Burcombe, J. Wei, R. Jiang, J. Kong, Y. Chen, ACS Nano, $2011, \mathbf{5}, 6971-6980$.

15. Y. Zhou, Y. Kong, S. Kundu, J. D. Cirillo and H. Liang, Journal of Nanobiotechnology, 2012, $10,1-9$.

16. R.F., Al-Thani, N. K. Patan and M. A. Al-Maadeed, Online Journal of Biological Sciences, $2014,14,230-239$.

17. W. Hu, C. Peng,W. Luo, M. Lv, X. Li, D. Li, Q. Huang, C. Fan, ACS Nano, 2010, 4, 43174323.

18. S. Gurunathan, J. W. Han, A. A. Dayem, V. Eppakayala, and J. H. Kim, International Journal of Nanomedicine., 2012, 7, 5901-5914.

19. C. Wu, A. R. Deokar, J.-H. Liao, P.-Y. Shih, Y.-C. Ling, ACS Nano. , 2013, 7, 1281-1290.

20. M. R. Das, K., R. Sarma, R. Saikia, V.S. Kale, M.V. Shelke, P. Sengupta. Colloids and Surfaces B: Biointerfaces, 2011, 83, 16-22.

21. M. R. Das, R. K. Sarma, S. C. Borah, R. Kumari, R. Saikia, A. B. Deshmukh, et al., Colloids and Surfaces B: Biointerfaces 2013, 105, 128-136.

22. N. Hussain, A. Gogoi, R. K. Sarma, P. Sharma, A. Barras, R. Boukherroub, R. Saikia, P. Sengupta, M. R. Das, Chempluschem., 2014, 79, 1774-1784. 
23. C. M. Santos, M. C. R. Tria, R. A. M. V. Vergara, F. Ahmed, R. C. Advincula and D. F. Rodrigues, Chemical Communications, 2011, 47, 8892-8894.

24. C. M Santos' J. Mangadlao, F. Ahmed, A. Leon, R. C. Advincula and D. F Rodrigues, Nanotechnology 2012, 23, 395101

25. K. Krishnamoorthy, M. Veerapandian, L.-H. Zhang, K. Yun and S. J. Kim, Journal of Physical Chemistry - C, 2012, 116, 17280-17287

26. C. Zhao, S. Pandit, Y. Fu, I. Mijakovic, A. Jesorka and J. Liu, RSC Advances, 2016, 6, 38124 $-38134$.

27. F. Perreault, A. F. de Faria, S. Nejati and M. Elimelech, ACS Nano 2015, 9, 7226 - 7236.

28. J. Li, G. Wang, H. Zhu, M. Zhang, X. Zheng, Z, Di, X. Liu and X. Wang, Scientific Reports, 2014, 4, 4359.

29. O. Akhavan and E. Ghaderi, ACS Nano, 2010, 4, 5731 - 5736.

30. C. Cha, S. R. Shin, N. Annabi, M. R. Dokmeci and A. Khademhosseini, ACS Nano, 2013, 7, 2891-2897.

31. A. Krueger, in Carbon Materials and Nanotechnology, Wiley-VCH Verlag GmbH \& Co. KGaA, 2010, pp. 1-32.

32. Y. Song, W. Wei, X. Qu, Advanced Materials 2011, 23, 4215-4236.

33. T. Kuila, S. Bose, A. K. Mishra, P. Khanra, N.H. Kim, J.H. Lee, 2012, Progress in Material Science 57, 1061-1105.

34. H. Bai, C. Li, G. Shi, Advanced Materials 23, 1089-1115.

35. L. Feng, Z. Liu, Nanomedicine, 2011, 6, 317-324.

36. Z. Liu, J.T. Robinson, X. Sun, H. Dai, Journal of American Chemical Society 2008, 130, $10876-10877$.

37. K. Yang, S. Zhang, G. Zhang, X. Sun, S. T. Lee, Z. Liu, Nano Letters, 2010, 10, 3318-3323.

38. J. L. Li, H.-C. Bao, X.-L. Hou, L. Sun, X. G. Wang, M. Gu, Angewandte Chemie International Edition, 2012, 51, 1830-1834.

39. M. Li, X. Yang, J. Ren, K. Qu, X, Qu, Advanced Materials, 2012, 24, 1722-1728.

40. Y. Tao, Y. Lin, Z. Huang, J. Ren, X. Qu, Advanced Materials 2013, 25, 2594-2599. 
41. N. Mohanty, V. Berry, Nano Letters, 2008, 8, 4469-4476.

42. L. Feng, L. Wu, X. Qu, Advanced Materials, 2013, 25, 68-186.

43. S. Liu, T. H. Zeng, M. Hofmann, E. Burcombe, J. Wei, R. Jiang, J. Kong and Y. Chen, ACS Nano, 2011, 5, 6971-6980.

44. E. Zanni, G. De Bellis, M. P. Bracciale, A. Broggi, M. L. Santarelli, M. S. Sarto, C. Palleschi and D. Uccelletti, Nano Letters, 2012, 12, 2740-2744.

45. J. Wang, N. Huang, P. Yang, Y. X. Leng, H. Sun, Z. Y. Liu and P. K. Chu, Biomaterials, 2004, 25, 3163-3170.

46. A. Shteynle, Proceedings on the $7^{\text {th }}$ International Forum on Strategic Technology, 2012.

47. Y. Liu, Z. Ren, Y. Wei, B. Jiang, S. Feng, L. Zhang, W. Zhang and H. Fu, Journal of Materials Chemistry, 2010, 20, 4802-4808.

48. A. Lerf, H. He, M. Forster and J. Klinowski, The Journal of Physical Chemistry B, 1998, 102, $4477-4482$.

49. J. L. Hobman and N. L. Brown, Metal Ions in Biological Systems, 1997, 34, 527-568.

50. C. Nethravathi and M. Rajamathi, Carbon, 2008, 46, 1994-1998.

51. M. Ciszewski and A. Mianowski, Materials Science-Poland, 2014, 32, 307-314.

52. S. Stankovich, D. A. Dikin, R. D. Piner, K. A. Kohlhaas, A. Kleinhammes, Y. Jia, Y. Wu, S. T. Nguyen and R. S. Ruoff, Carbon, 2007, 45, 1558-1565.

53. Y. Zhu, S. Murali, W. Cai, X. Li, J. W. Suk, J. R. Potts and R. S. Ruoff, Advanced Materials, 2010, 22, 3906-3924.

54. S. Liu, T. H. Zeng, M. Hofmann, E. Burcombe, J. Wei, R. Jiang, J. Kong and Y. Chen, Acs Nano, 2011, 5, 6971-6980.

55. J. S. Chen, Z. Wang, X. C. Dong, P. Chen and X. W. Lou Nanoscale, 2011, 3, 2158-2161

56. W. Gao, L. B. Alemany, L. Ci and P. M. Ajayan, Nature Chemistry, 2009, 1, 403-408.

57. A. L. Casey, D., Adams, T. J. Karpanen, P. A. Lambert, B. D. Cookson, P. Nightingale, L. Miruszenko, R. Shillam, P. Christian, T. S .J. Elliott, Journal of Hospital Infection, 2010, 74, $72-77$. 
58. S. Silver, T. Phung, G. Silver, Journal of Industrial Microbiology and Biotechnology, 2006, $33,627-634$.

59. Z. Liu, J.T. Robinson, X. Sun, H. Dai, Journal of the American Chemical Society, 2008, 130, $10876-10877$.

60. C. Dai, X. Yang and H. Xie, Materials Research Bulletin, 2011, 46, 2004-2008.

61. Y. Gerasymchuk, A. Lukowiak, A. Wedzynska, A. Kedziora, G. Bugla-Ploskonska, D. Piatek, T. Bachanek, V. Chernii, L. Tomachynski and W. Strek, Journal of Inorganic Biochemistry, 2016, 159, 142-148.

62. A. K. Geim and K. S. Novoselov, Nature Materials, 2007, 6, 183-191.

63. D. A. C. Brownson, D. K. Kampouris and C. E. Banks, Chemical Society Reviews, 2012, 41, 6944-6976.

64. F. Taherian, V. Marcon, N. F. van der Vegt and F. d. r. Leroy, Langmuir, 2013, 29, 1457-1465.

65. M. Dallavalle, M. Calvaresi, A. Bottoni, M. Melle-Franco and F. Zerbetto, ACS Applied Materials \& Interfaces, 2015, 7, 4406-4414.

66. X. Zou, L. Zhang, Z. Wang and Y. Luo, Journal of the American Chemical Society, 2016, 138, 2064-2077.

67. S. Bykkam, S. Narsingam, M. Ahmadipour, T. Dayakar, K. Venkateswara Rao, C. Shilpa Chakra and S. Kalakotla, Superlattices and Microstructures, 2015, 83, 776-784.

68. O. Akhavan and E. Ghaderi, ACS Nano, 2010, 4, 5731-5736.

69. L. Zhong and K. Yun, International Journal of Nanomedicine, 2015, 10, 79-92.

70. A. Janković, S. Eraković, M. Vukašinović-Sekulić, V. Mišković-Stanković, S. J. Park and K. Y. Rhee, Progress in Organic Coatings, 2015, 83, 1-10.

71. C. M. Santos, J. Mangadlao, F. Ahmed, A. Leon, R. C. Advincula and D. F. Rodrigues, Nanotechnology, 2012, 23, 395101.

72. S. Ye, K. Shao, Z. Li, N. Guo, Y. Zuo, Q. Li, Z. Lu, L. Chen, Q. He and H. Han, ACS Applied Material Interfaces, 2015, 7, 21571-21579.

73. D. Bitounis, H. Ali-Boucetta, B. H. Hong, D. H. Min and K. Kostarelos, Advanced Materials, 2013, 25, 2258-2268. 
74. F. Perreault, M. E. Tousley and M. Elimelech, Environmental Science \& Technology Letters, $2014,1,71-76$.

75. T. Tian, X. Shi, L. Cheng, Y. Luo, Z. Dong, H. Gong, L. Xu, Z. Zhong, R. Peng and Z. Liu, ACS Applied Material Interfaces, 2014, 6, 8542-8548.

76. A. F. de Faria, D. S. T. Martinez, S. M. M. Meira, A. C. M. de Moraes, A. Brandelli, A. G. S. Filho and O. L. Alves, Colloids and Surfaces B: Biointerfaces, 2014, 113, 115-124.

77. S. Pei and H.-M. Cheng, Carbon, 2012, 50, 3210-3228.

78. V. Loryuenyong, K. Totepvimarn, P. Eimburanapravat, W. Boonchompoo and A. Buasri, Advances in Materials Science and Engineering, 2013, 2013, 5.

79. S.-J. Chang, M. S. Hyun, S. Myung, M.-A. Kang, J. H. Yoo, K. G. Lee, B. G. Choi, Y. Cho, G. Lee and T. J. Park, Scientific Reports, 2016, 6, 22653.

80. A. Iwase, Y. H. Ng, Y. Ishiguro, A. Kudo and R. Amal, Journal of the American Chemical Society, 2011, 133, 11054-11057.

81. C. Wong, C. Lai, K. Lee and S. Hamid, Materials, 2015, 8, 5363.

82. S. Barua, S. Thakur, L. Aidew, A. K. Buragohain, P. Chattopadhyay and N. Karak, RSC Advances, 2014, 4, 9777-9783.

83. M. Mehrali, E. Moghaddam, S. F. S. Shirazi, S. Baradaran, M. Mehrali, S. T. Latibari, H. S. C. Metselaar, N. A. Kadri, K. Zandi and N. A. A. Osman, ACS Applied Materials \& Interfaces, 2014, 6, 3947-3962.

84. J. Jeong, J. Y. Kim and J. Yoon, Environmental Science \& Technology, 2006, 40, 6117-6122.

85. O. Akhavan and E. Ghaderi, The Journal of Physical Chemistry C, 2009, 113, 20214-20220.

86. T. H. Yuzuriha and D. W. Hess, Thin Solid Films, 1986, 140, 199-207.

87. A. F. Khan, D. A. C. Brownson, E. P. Randviir, G. C. Smith and C. E. Banks, Analytical Chemistry, 2016, 88, 9729-9737.

88. J. S. Maria Nithya and A. Pandurangan, RSC Advances, 2014, 4, 32031-32046.

89. Z. Wang, Z. Dong, Y. Gu, Y.-H. Chang, L. Zhang, L.-J. Li, W. Zhao, G. Eda, W. Zhang, G. Grinblat, S. A. Maier, J. K. W. Yang, C.-W. Qiu and A. T. S. Wee, Nature Communications, $2016,7,11283$. 
90. G. R. Navale, C. S. Rout, K. N. Gohil, M. S. Dharne, D. J. Late and S. S. Shinde, RSC Advances, $2015, \mathbf{5}, 74726-74733$.

91. X. Yu, M. S. Prévot, N. Guijarro and K. Sivula, Nature Communications, 2015, 6, 7596.

92. F. Vatansever, W. C. de Melo, P. Avci, D. Vecchio, M. Sadasivam, A. Gupta, R. Chandran, M. Karimi, N. A. Parizotto, R. Yin, G. P. Tegos and M. R. Hamblin, FEMS Microbiology Reviews, 2013, 37, 955-989.

93. G. S. Bang, S. Cho, N. Son, G. W. Shim, B.-K. Cho and S.-Y. Choi, ACS Applied Materials \& Interfaces, 2016, 8, 1943-1950.

94. P. A. Tran and T. J. Webster, Nanotechnology, 2013, 24, 155101.

95. B. Liu, M. Fathi, L. Chen, A. Abbas, Y. Ma and C. Zhou, ACS Nano, 2015, 9, 6119-6127.

96. X. Yang, J. Li, T. Liang, C. Ma, Y. Zhang, H. Chen, N. Hanagata, H. Su and M. Xu, Nanoscale, 2014, 6, 10126-10133.

97. N. Qureshi, R. Patil, M. Shinde, G. Umarji, V. Causin, W. Gade, U. Mulik, A. Bhalerao and D. P. Amalnerkar, Applied Nanoscience, 2015, 5, 331-341.

98. W. Zhang, S. Shi, Y. Wang, S. Yu, W. Zhu, X. Zhang, D. Zhang, B. Yang, X. Wang and J. Wang, Nanoscale, 2016, 8, 11642-11648. 